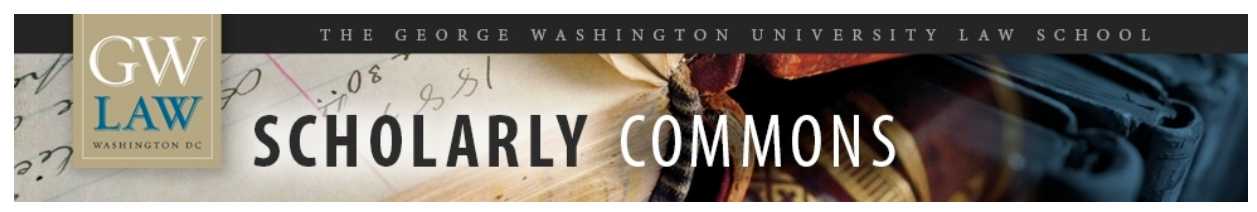

\title{
What Should We Do About Administrative Law Judge Disability Decisionmaking?
}

Richard J. Pierce Jr

George Washington University Law School, rpierce@law.gwu.edu

Follow this and additional works at: https://scholarship.law.gwu.edu/faculty_publications

Part of the Law Commons

\section{Recommended Citation}

Pierce, Richard J. Jr, "What Should We Do About Administrative Law Judge Disability Decisionmaking?" (2011). GW Law Faculty Publications \& Other Works. 851.

https://scholarship.law.gwu.edu/faculty_publications/851

This Article is brought to you for free and open access by the Faculty Scholarship at Scholarly Commons. It has been accepted for inclusion in GW Law Faculty Publications \& Other Works by an authorized administrator of Scholarly Commons. For more information, please contact spagel@law.gwu.edu. 


\title{
What Should We Do About Administrative Law Judge Disability Decisionmaking?
}

\author{
Richard J. Pierce, Jr. ${ }^{1}$
}

\section{The Scope and Sources of the Problem}

The 1400 Administrative Law Judges (ALJs) who work for the Social Security Administration $(\mathrm{SSA})^{2}$ are making a significant contribution to the economic problems the US is now experiencing. When an applicant for Social Security disability benefits receives two negative decisions from the SSA, he can appeal to an ALJ. Over the past four decades, the proportion of the US population that has been determined to be permanently disabled has more than doubled. ${ }^{3}$ The cost of the disability program has increased over four-fold over the past two decades. ${ }^{4}$ During that period, the cost of disability benefit awards increased from 10 per cent of SSA's total budget to 18 per cent of that budget. ${ }^{5}$ Annual payments from the trust fund that was established to pay disability benefits are now $\$ 124$ billion dollars-one per cent of total US GDP. ${ }^{6}$ As a

\footnotetext{
${ }^{1}$ Lyle T. Alverson Professor of Law, George Washington University. I am indebted to Rob Glicksman, Jerry Mashaw, and the participants in a works in progress luncheon at George Washington University for providing helpful comments on an earlier version of this essay. I am also indebted to Autumn Houston for providing research assistance on this project.

${ }^{2}$ U.S. Social Securty Administration, ALJ Disposition Data. Fiscal Year 2011, http://www.ssa.gov/appeals/DataSets/03 ALJ Disposition Data.pdf.

${ }^{3}$ U.S. Social Securty Administration, Office of Policy, Trends in the Social Security and Supplemental Security Income Disability Programs, http://www.ssa.gov/policy/docs/chartbooks/disability trends/sect01.html.

${ }^{4}$ Id. See also Congressional Budget Office, Social Security Disability Insurance: Participation Rates and Their Fiscal Implications (July 2010); David Autor \& Mark Duggan, The Growth in the Social Security Disability Rolls: A Fiscal Crisis Unfolding, 20 J.Econ. Perspectives 71 (2006).

${ }^{5}$ Id.

${ }^{6}$ U.S. Social Security Administration, Trustees 2011 Report Summary, Actuarial Publications, Status of the Social Security and Medicare Programs, http://www.ssa.gov/oact/trsum/index.html.
} 
result, that fund is expected to be exhausted by 2018, many years before the expected exhaustion of the Social Security or Medicare trust funds. ${ }^{7}$

The large increase in the proportion of the US population that has been determined to be permanently disabled is also having broader adverse effects on the performance of the US economy. The proportion of US adult males who are available for work has declined from 80 per cent in 1970 to 71 per cent in $2010 .^{8}$ As The Economist has documented "Widespread male worklessness has huge economic, fiscal, and social costs."9

Most of the increase in the proportion of the population that has been determined to be permanently disabled is attributable to ALJ decisions that reversed initial SSA decisions that denied applications for benefits on the basis of determinations that the applicants were not disabled. Thus, for instance, a single SSA ALJ overruled SSA and awarded benefits to 2285 applicants in 2007 , at a cost to taxpayers of $\$ 2.1$ billion. $^{10}$ Unless we address this problem promptly and effectively, it will increase in severity and scope. As the tendency of ALJs to grant benefits that SSA twice denied has become wellknown, there has been a predictable increase in the number of applications for benefits.

\footnotetext{
${ }^{7} \mathrm{Id}$.

${ }^{8}$ Marlene A. Lee and Mark Mather, U.S. Labor Force Trends, PopulAtion BULletin, Vol. 63, No. 2 , (June 2008), http://www.prb.org/pdf08/63.2uslabor.pdf.; Bureau of Labor Statistics, International Comparisons of Annual Labor Force Statistics 31 (Mar. 30, 2011).

9 America's Jobless Men: Decline of the Working Man, The Economist (Apr. 28, 2011). This article was part of a series of articles in which The Economist has linked excess disability payments to the poor performance of the US economy. See, e.g., Disability Payments: The Elephant in the Waiting Room, The Economist (Mar. 10, 2011); Unemployment: Which Workers Will Need Jobs, The Economist (Sep. 14, 2010); America's Labor Market: Something's Not Working, The Economist (Apr. 29, 2010).

${ }^{10}$ Mark Friesen, Paying Out Billions, One Judge Attracts Criticism, The Oregonian (Dec. 29, 2008); The Oregonian, Social Security Database, (Friday, June 18, 2010)http://www.oregonlive.com/special/index.ssf/2008/12/social_security_database.html (last visited July $11,2011)$.
} 
In 2008 alone, the number of applications increased by 21 per cent, to 2.8 million, ${ }^{11}$ and the backlog of cases pending before ALJs reached 752,000. ${ }^{12}$ The number of decisions granting benefits increased 28 per cent between 2007 and $2010 .{ }^{13}$ Since the average cost of a decision granting disability benefits is $\$ 245,000,{ }^{14}$ and ALJs grant benefits in $60 \%$ of cases, ${ }^{15}$ the total cost of the pending cases alone will be about $\$ 117$ billion. As a practical matter, ALJ decisions that grant disability benefits are final and irrevocable commitments of taxpayer funds. SSA lacks the resources to review ALJ decisions that grant benefits, ${ }^{16}$ and less than one per cent of individuals who are awarded benefits ever leave the rolls of beneficiaries. ${ }^{17}$

If there was reason to believe that all, or even most, ALJ decisions granting disability benefits were accurate reflections of the health status of the individual applicants, I would reluctantly accept the high cost of those decisions as one of the costs of living in a humane and compassionate country. There is no reason to indulge that belief, however, and there are many reasons to reject it as highly unlikely.

First, most of the applicants who are awarded benefits by ALJs are determined by the ALJ to have a "nonexertional restriction" - either a mental condition such as anxiety or depression or pain attributable to a musculoskeletal condition. ${ }^{18}$ Thus, for instance,

\footnotetext{
${ }^{11}$ U.S. Social Security Administration, Selected Data from Social Security's Disability Program, DisabledWorker Statistics, http://www.ssa.gov/oact/STATS/dibStat.html.

${ }^{12}$ U.S. Social Security Administration, Plan to Eliminate the Hearing Backlog and Prevent Its Recurrence, Annual Report, Fiscal Year 2008, http://www.ssa.gov/appeals/Backlog_Reports/Annual_Backlog_Report_FY 2008-Jan.pdf.

${ }^{13}$ Id.

${ }^{14}$ Autor \& Duggan, note 4, supra. at 73.

${ }^{15}$ U.S. Social Security Administration, ALJ Disposition Data. Fiscal Year 2011, http://www.ssa.gov/appeals/DataSets/03 ALJ Disposition Data.pdf.

${ }^{16} \mathrm{CBO}$, supra. note 4 , at 6 .

${ }^{17}$ Id. at 4.

${ }^{18}$ Jon Dubin discusses this phenomenon at length in Jon Dubin, Overcoming Gridlock: Campbell and Bureaucratically Rational Gap-Filling in Mass Justice Adjudication in the Social Security Administration's Disability Programs, 62 Admin. L. Rev. 937, 942-47 (2010). See also
} 
between 1983 and 2003, awards based on nonexertional restrictions increased 323 per cent; by 2003, they accounted for over half of all awards. ${ }^{19}$ Nonexertional restrictions have characteristics that are important in evaluating disability decisions. There are no objective diagnostic criteria that can be used to verify or refute a claim that an individual has a nonexertional restriction. ${ }^{20}$ Moreover, all such restrictions are matters of degree. The Social Security Act renders an individual eligible for disability benefits only if he has an impairment "of such severity that he . . cannot . . . engage in any . . . kind of substantial gainful work which exists in the national economy." ${ }^{21}$ Yet, there are no objective diagnostic criteria that can be used to measure the degree of an applicant's anxiety, depression, or pain. ${ }^{22}$ Finally, nonexertional restrictions are ubiquitous. The National Institute of Medicine has found that 116,000,000 americans suffer from chronic pain, ${ }^{23}$ while the National Institute of Mental Health has found that $61,000,000$ americans suffer from mentqal disease. ${ }^{24}$ It is a rare person who reaches my age (68) without having experienced anxiety, depression, and/or pain over some significant periods of time. Thus, at some point in his life, almost every person can make a plausible claim of eligibility for permanent disability benefits based on nonexertional restrictions. That claim can neither be supported nor refuted based on application of objective diagnostic criteria

Second, the patterns of ALJ decisions granting or denying disability benefits vary greatly among ALJs. Studies of ALJ disability decisionmaking have documented massive unexplained differences in the rate at which ALJs grant or deny benefits. Thus, for

\footnotetext{
${ }^{19}$ Autor \& Duggan, supra. note 4, at 79.

${ }^{20}$ Report of the Commission on the Evaluation of Pain 51-58, 81-87 (1986); Jerry Mashaw, Bureaucratic Justice 52-64, 61-64, 110 (1983); Jerry Mashaw, Charles Goetz, Frank Goodman, Warren Schwartz, Paul Verkuil, and Milton Carrow, Social Security Hearings and Appeals 15-19,101-109,139 (1978).

${ }^{21} 42$ U.S.C. $\$ 423(\mathrm{~d})(2)(\mathrm{A})$.

${ }^{22}$ See sources cited in note 20 supra.

${ }^{23}$ National Institute of Medicine, Relieving Pain in America (2011).

${ }^{24}$ National Institute of Mental Health website (last visited on July 18, 2011).
} 
instance, a study of ALJ decisions made in 1976 found that, while 45\% of ALJs granted benefits in 40 to $60 \%$ of cases, $12 \%$ granted benefits in less than $28 \%$ of cases and $10 \%$ granted benefits in over $72 \%$ of cases. ${ }^{25}$ Given the large number of cases randomly assigned to each ALJ, variations of that magnitude can only be explained as a reflection of the widely differing attitudes of ALJs. ${ }^{26}$ As a team of six scholars concluded in 1978: "the outcome of cases depends more on who decides the case than on what the facts are." $^{27}$

The variation in the decisionmaking patterns of ALJs has increased significantly since the 1970s. In the first half of 2011, for instance, the average rate at which ALJs awarded benefits was $60 \%,{ }^{28}$ but 100 ALJs awarded benefits in over $90 \%$ of cases ${ }^{29}$ while 27 ALJs awarded benefits in over $95 \%$ of cases. ${ }^{30}$ That dramatic difference in grant rates is inherently inconsistent with an accurate decisionmaking process.

Third, the temporal pattern of ALJ disability decisions is inconsistent with a belief in the accuracy of those decisions. Both the average ALJ grant rate and the distribution of ALJ grant rates have increased dramatically over the past three decades. ${ }^{31}$ The net effect has been a doubling of the proportion of the population that has been determined to be permanently disabled. If ALJ disability decisions are an accurate reflection of the health of the US population, we are experiencing a public health crisis. If we are to believe ALJ

\footnotetext{
${ }^{25}$ Mashaw et al., supra. note 20 ,at 21-24.

${ }^{26}$ Richard Pierce, Political Control Versus Impermissible Bias in Agency Decisionmaking, 57 U.Chi. L. Rev. 481, 509 (1990).

${ }^{27}$ Mashaw et al. supra. note 20, at xxi.

${ }^{28} \mathrm{Id}$.

${ }^{29} \mathrm{Id}$.

${ }^{30} \mathrm{Id}$.

${ }^{31}$ Compare the chart in Mashaw et al, supra. note 20, at 21, with the chart in Social Security Advisory Board, Improving the Social Security Administration's Hearing Process 5 (2006).
} 
decisions, the incidence of permanent disability in the US population has more than doubled since $1970 .{ }^{32}$ That belief is beyond implausible.

Fourth, every case in which an ALJ grants disability benefits is a case in which the SSA bureaucracy has twice determined that the applicant is not disabled. ${ }^{33}$ The initial bureaucratic decision is made by a team that consists of a disability examiner and a medical advisor. The team analyzes the paper record, including the submissions of the applicant and the applicant's treating physicians. The decisionmaking team can solicit such additional medical information as it determines to be needed to complete the record and can order such further examinations by consultative physicians as it determines to be needed to make an accurate determination of disability. If the initial team of decisionmakers denies the application, the applicant can request and obtain a second determination by a new examiner/medical advisor team. The new team can, and often does, order additional consultative examinations. SSA implements a quality assurance program in which it evaluates the decisions of the examiner/medical advisor teams to ensure the accuracy of their decisions and to provide feedback and training to disability examiners and medical advisors to the extent that the quality assurance office identifies flaws or gaps in the decisionmaking process.

If both the first examiner/medical advisor team and the second examiner/medical advisor team find that the applicant is not disabled, the applicant can obtain a de novo oral hearing before an ALJ. The applicant can be, and usually is, represented by counsel

\footnotetext{
${ }^{32}$ U.S. Social Securty Administration, Office of Policy, Trends in the Social Security and Supplemental Security Income Disability Programs, http://www.ssa.gov/policy/docs/chartbooks/disability trends/sect01.html.

${ }^{33}$ The decisionmaking process is described in Robert Glicksman \& Richard Levy, Administrative Law: Agency Action in Legal Context 581-82 (2010). See also Mathews v. Eldridge, 424 U.S. 319, 337 (1976).
} 
at that hearing. ${ }^{34}$ The government is never represented at a hearing before an ALJ. The only government employee at the hearing is the ALJ, who has a duty to assist the applicant in the development of evidence in support of his claim. ${ }^{35}$ If the ALJ finds that the applicant is disabled, that decision is final as a practical matter. In theory, SSA can review an ALJ decision that grants an application for benefits, but its past efforts to do so have been thwarted by a combination of judicial resistance and inadequate funding. ${ }^{36}$

The decision to allow an applicant to appeal two negative decisions made by two examiner/medical advisor teams to an ALJ and to allow an ALJ's decision to grant an application for benefits that has been rejected twice by the bureaucracy to become final must be based on the belief that ALJ decisions are more likely to be accurate than decisions made by two independent examiner/medical advisor teams. There is no basis for that belief, however, and many reasons for the contrary belief. The ALJ has no medical education and, unlike a disability examiner, the ALJ has no medical advisor. Moreover, unlike the examiner/medical advisor teams, the ALJ's decisionmaking process is not subject to any form of evaluation or other means of assuring the quality of the decisionmaking process. SSA is prohibited from supervising ALJs or evaluating their performance, ${ }^{37}$ and SSA's past efforts to implement quality assurance programs applicable to ALJs have been abandoned as a result of hostility from district courts and lack of adequate resources. ${ }^{38}$

\footnotetext{
${ }^{34}$ Autor \& Duggan, note 4 supra., at 88.

${ }^{35} 20$ C.F.R. $\S \S 404.1512$ (d), $416.912(d-f)$.

${ }^{36}$ See text at notes 63-68 infra.

${ }^{37} 5$ U.S.C. $\S 4301(2)(D) ; 5$ C.F.R. $\S 930.211$. See the detailed discussion in Paul Verkuil, Daniel Gifford, Charles Koch, Jeffrey Lubbers \& Richard Pierce, The Federal Administrative Judiciary 133-62 (1992).

${ }^{38}$ See text at notes 71-81 infra.
} 
The belief that ALJ decisions are more likely to be accurate than bureaucratic decisions must be based on the belief that oral hearings yield more accurate findings of fact than decisions based on paper hearings. That belief, in turn, must be based primarily on the belief that the ability to observe the demeanor of a witness helps a decisionmaker determine whether the witness is providing honest and accurate testimony. That belief is longstanding, but it is supported by no evidence, and it is contradicted by a large body of evidence in the psychology literature. ${ }^{39}$

The Executive Branch of government is powerless to address the growing problem of ALJs' unwarranted commitment of billions of dollars to undeserving applicants for disability benefits. On May 19, 2011, The Wall Street Journal published a front page article in which it focused attention on an ALJ who had awarded benefits in $100 \%$ of the 729 cases he decided in the first six months of fiscal 2011 and in 1280 of the 1284 cases he decided in $2010 .{ }^{40}$ It quoted the Commissioner of Social Security: "We mostly have a very productive judiciary that makes high-quality decisions, and we've got some outliers and we've done what we can. Our hands are tied on some of the more extreme cases." ${ }^{41}$ A week later, the Commissioner apparently changed his views and attempted to address the problem that the Journal highlighted. SSA suspended the ALJ indefinitely. ${ }^{42}$

There are two problems with the SSA response to the problem. First, it is patently inadequate. The problem is not limited to one or even a few outliers. Many ALJs grant

\footnotetext{
${ }^{39}$ Richard Lempert, Samuel Gross, James Liebman, John Blume, Stephen Landsman \& Frederick Lederer, A Modern Approach to Evidence 526-27 (4 ${ }^{\text {th }}$ ed. 2011); Olin Wellborn, Demeanor, 76 Corn. L. Rev. 1075, 1078-91 (1991).

${ }^{40}$ Damien Paletta, Disability-Claim Judge Has Trouble Saying 'No' Wall Street Journal (May 19, 2011).

${ }^{41}$ Id.

${ }^{42}$ Damien Paletta, Disability Judge Put on Leave from Post, Wall Street Journal (May 27, 2011).
} 
benefits at indefensibly high rates. ${ }^{43}$ Second, the SSA action against the ALJ is not within SSA's power to take. An agency can take an action of any type against an ALJ, specifically including suspension, only if it persuades another ALJ at the Merit Systems Protection Board (MSPB) that it has "good cause" to take the action. ${ }^{44}$ That is extremely difficult in general and impossible in a context in which the ALJ's pattern of decisions is the putative basis for the removal attempt.

A case that the Federal Circuit decided in 2011 illustrates the difficulty of the task of removing an ALJ even in extreme circumstances. ${ }^{45}$ An SSA ALJ beat his domestic partner and his young child. ${ }^{46}$ The two victims fled to the house of friends, who called the police. ${ }^{47}$ The police took pictures of the damage to the faces of the victims and charged the ALJ with battery. ${ }^{48}$ SSA filed a petition with MSPB in which it sought to remove the ALJ for good cause. ${ }^{49}$ MSPB assigned the case to another ALJ. The presiding ALJ found that the defendant ALJ had not beaten his child and had not struck his domestic partner with his fist. ${ }^{50}$ The presiding ALJ stated that he believed the testimony of the defendant ALJ and disbelieved the testimony of the several witnesses who testified for SSA. ${ }^{51}$ On review of the ALJ's initial decision, MSPB issued an opinion in which it found that the defendant ALJ had hit his child and hit his domestic partner with his fist. MSPB then held that the ALJ could be removed for good cause. ${ }^{52}$

\footnotetext{
${ }^{43}$ Text at notes $28-31$ supra.

445 U.S.C. $\$ 7521$.

${ }^{45}$ Long v. Social Security Administration, 635 F.3d 526 (Fed. Cir. 2011).

${ }^{46}$ Id. at 528.

${ }^{47}$ Id. at 528 .

${ }^{48}$ Id. at 528.

${ }^{49}$ Id. at $528-29$.

${ }^{50}$ Id. at 529.

${ }^{51}$ Id. at 529.

${ }^{52}$ Id. at 529.
} 
The presiding ALJ based his findings of fact on his observation of the demeanor of the witnesses. ${ }^{53}$ That was an obvious attempt to insulate his findings and his decision from potential reversal by MSPB. The Administrative Procedure Act gives an agency the power to reject an initial decision of an ALJ on appeal. Specifically, the APA provides: "On appeal from or review of the initial decision, the agency has all of the powers which it would have in making the initial decision." 54 The Supreme Court has interpreted that provision to allow an agency to replace the findings of fact made by an ALJ with the agency's own findings of facts inconsistent with those of the ALJ as long as the agency's findings are supported by substantial evidence. ${ }^{55}$ Like most circuit courts, however, the Federal Circuit has qualified the APA and the Supreme Court's interpretation of the APA in the context of findings based on demeanor. Under Federal Circuit precedent, when an ALJ makes findings based on demeanor, an agency can substitute its findings for those of the ALJ only by satisfying an unusually demanding duty to explain its action. ${ }^{56}$

Courts have long attached great significance to the ability of a trier of facts to observe a witness's demeanor. That judicial tradition is not supported by any evidence, however. Indeed, there is a substantial body of research that has consistently concluded that observation of a witness's demeanor is not at all helpful in determining whether a witness is providing honest and accurate testimony. ${ }^{57}$

The Federal Circuit upheld the MSPB decision that rejected the presiding ALJ's findings of fact and upheld the agency's decision to remove the ALJ for good cause. ${ }^{58}$

\footnotetext{
${ }^{53}$ Id. at 530.

${ }^{54} 5$ U.S.C. $\$ 557(b)$.

${ }^{55}$ Richardson v. Perales, 402 U.S. 389 (1971).

${ }^{56}$ Leatherby v. Dep't of the Army, 524 F.3d 1293, 1304 (Fed. Cir. 2008).

${ }^{57}$ Sources in note 39, supra.

${ }^{58} 635$ F.3d at 530-31.
} 
The court concluded that MSPB had met its burden of explaining adequately why it rejected the presiding ALJ's findings of fact. One judge wrote a concurring opinion, however, in which he expressed concern about the MSPB's basis for its findings and suggested that he would have decided the case for the defendant ALJ in another case that did not involve facts that were so "unusual.",59 It seems highly unlikely that the court would uphold an MSPB decision removing an ALJ for good cause in the much less "unusual" case of an ALJ who has granted benefits in all, or virtually all, of the cases he has decided. Indeed, most courts have reacted with hostility to more subtle SSA attempts to exercise any degree of control over the decisionmaking patterns of ALJs. ${ }^{60}$

\section{Potential Solutions}

\section{A. Require employers to share the cost of disability decisions}

There are many directions we could take in an effort to address this problem. Some scholars urge adoption of the approach that seems to be yielding improvements in the Netherlands. Dutch law now requires that an applicant's employer pay part of the costs of providing disability benefits for the initial years a beneficiary receives benefits. ${ }^{61}$ By requiring employers to bear that cost, the Dutch system gives employers incentives to

\footnotetext{
${ }^{59}$ Id. at 538-39.

${ }^{60}$ Text at notes 71-81 infra.

${ }^{61}$ Organization of Economic Cooperation and Development, Sickness and Disability Schemes in the Netherlands, (November 2007), http://www.oecd.org/dataoecd/35/30/41429917.pdf.
} 
accommodate an individual's disabilities in various ways, to provide an individual with training that will enable him to perform another job that is within his new more limited capabilities, and to contest an individual's claim of disability.

This option may be worth consideration in the U.S. I do not know how much employers can do to discourage potential applicants from seeking disability benefits through accommodation or assistance, but I am confident that giving employers an incentive to contest an applicant's claim in a proceeding before an ALJ would reduce the number of cases in which ALJs grant benefits to undeserving applicants. At present, when an applicant appears before an ALJ, he is usually represented by a lawyer who can earn as much as $\$ 6000$ if he can persuade the ALJ to grant his client benefits. ${ }^{62}$ The ALJ, in turn, has a duty to assist the applicant in gathering and presenting the evidence required to determine whether he is disabled. No one represents the agency or the taxpayer in disability proceedings before an ALJ. If employers were required to bear a significant share of the total cost of a grant of disability benefits, they would be likely to retain lawyers to contest applications by employees they believe to be undeserving and the presence of lawyers opposing undeserving applicants would change the outcome of many cases. As the proportion cases in which applicants succeeded in proceedings before ALJs declined, the number of applicants inevitably would decline as well. Of course, these results could be obtained more directly by adopting the proposal that the Social Security Advisory Board has long made to assign agency lawyers to represent the government in disability hearings. ${ }^{63}$

\footnotetext{
${ }^{62}$ U.S. Social Security Administration, Fee Agreements, http://www.ssa.gov/representation/fee agreements.html.

${ }^{63}$ Social Security Advisory Board, Charting the Future of Social Security's Disability Programs: The Need for Fundamental Change 19-20 (2001).
} 
I am sure that both the Bar and my students would appreciate the effects of this proposal in improving employment opportunities for lawyers. It has a potentially fatal cost, however. Converting a high proportion of disability cases before ALJs into hardfought adversarial proceedings undoubtedly would increase the average amount of time required to conduct each hearing. That, in turn, would reduce the number of cases each ALJ could decide, thereby increasing the waiting time for a hearing. Delay in the availability of ALJ hearings has long been one of the major problems in the disability decisionmaking process. That problem has increased in recent years as a result of the enormous increase in applications filed and hearings requested. The average waiting period in 2007 was 512 days. ${ }^{64}$ It is difficult to support a proposal that responds to one major problem - excessive generosity in the decisionmaking process - by exacerbating another major problem — undue delay in that process.

\section{B. Require SSA review of past decisions to grant benefits}

The United Kingdom is considering another potential solution-mandatory periodic review of all past decisions to grant disability benefits. ${ }^{65}$ Some sort of review process should be part of the US solution to the problem. SSA has engaged in review of past awards during some periods of time, with impressive results. SSA recovered $\$ 11$ in benefits that otherwise would have been paid to undeserving individuals for every $\$ 1$ it

\footnotetext{
${ }^{64}$ SSA OIG, Congressional Response Report: Hearing Office Disposition Rates (A-07-10-21015), January 2010. http://www.ssa.gov/appeals/DataSets/03 ALJ Disposition_Data.html

${ }^{65}$ Department for Work and Pensions, Disability Living Allowance Reform, page 4, 11 (December 2010), http://www.dwp.gov.uk/docs/dla-reform-consultation.pdf.
} 
spent engaging in review of prior awards. ${ }^{66}$ During the period 1980-83, SSA reviewed a large number of prior awards. SSA found that $40 \%$ of the beneficiaries whose cases it reviewed were not disabled. ${ }^{67}$ SSA's review programs have elicited strong pushback from courts, advocates for the disabled, and politicians, however. ${ }^{68}$ In recent years, SSA has largely abandoned its review programs. ${ }^{69}$ It has allocated virtually all of its scarce decisionmaking resources to an understandable effort to reduce the delays in the process of deciding whether to grant benefits. ${ }^{70}$ Thus, SSA must be able to identify some new source of resources to fund a review program.

\section{Implement SSA quality controls on ALJs}

SSA could attempt to address the problem by reinstituting some version of the ALJ quality control programs it implemented in the 1970s and early 1980s. During that period, SSA responded to the problem of delay in the ALJ decisionmaking process by announcing productivity goals for ALJs and it responded to the problems of inconsistency and excessive generosity in ALJ decisionmaking by announcing a presumptive range of decisions to grant benefits. ${ }^{71}$ That program elicited strong pushback from courts and from ALJs.

\footnotetext{
${ }^{66}$ U.S. Social Security Administration, Office of Audit's Fiscal Year 2010 Annual Work Plan, http://www.ssa.gov/oig/ADOBEPDF/audittxt/workplan2010.html.

${ }^{67}$ Autor \& Duggan, note 4, supra. , at 78.

${ }^{68}$ E.g., Lopez v. Heckler, 713 F.2d 1432 ( $9^{\text {th }}$ Cir. 1983); Patti v. Schweiker, 669 F.2d 582 (9 ${ }^{\text {th }}$ Cir. 1982); Finnegan v. Mathews, 641 F.2d $1340\left(9^{\text {th }}\right.$ Cir. 1981)

6969 U.S. General Accounting Office, Report to the Chairman, Subcommittee on Social Security, Committee on Ways and Means, House of Representatives, (July 2004), http://www.gao.gov/new.items/d04656.pdf.

${ }^{71}$ The programs are described in Pierce, note 26, at 503-10.
} 
After several district courts held that the program was an unlawful interference with the decisional independence of ALJs ${ }^{72}$ the Second Circuit issued an ambiguous opinion in which it seemed to uphold parts of the program. ${ }^{73}$ The court recognized that: "policies designed to insure a reasonable degree of uniformity among ALJ decisions are not only within the bounds of legitimate agency supervision but are to be encouraged." ${ }^{74}$ The court expressed "concern," however, that the presumptively permissible range of grants of benefits the agency had announced would put pressure on ALJs to deny benefits in some cases. ${ }^{75}$ The court characterized such an effect as "a clear infringement of decisional independence.," The court approved of SSA's "reasonable efforts to increase the production levels of ALJs", with the caveat that SSA could only establish reasonable goals and not unreasonable quotas.

The Second Circuit's ambivalent attitude toward the presumptive range of grant decisions SSA had announced, coupled with several district court opinions that excoriated SSA for announcing the presumptive range of grant decisions, undoubtedly contributed to the agency's decision to reconsider its program. SSA soon discovered, however, that the entire program, including the productivity measures the Second Circuit approved, was toothless.

SSA identified one ALJ who had consistently fallen below the minimum level of productivity that the Second Circuit seemed to have approved. SSA provided that ALJ with additional training and warned him that SSA would remove him for good cause if he

\footnotetext{
${ }^{72}$ E.g., Salling v. Bowen, 641 F. Supp. 1046, 1055, 1073 (W.D. Va. 1986); Association of Administrative Law Judges v. Heckler, 594 F. Supp. 1132, 1141-43 (D.D.C. 1984).

${ }^{73}$ Nash v. Bowen, 869 F.2d 675 (2d Cir. 1989).

${ }^{74}$ Id. at 680 .

${ }^{75} \mathrm{Id}$. at 681 .

${ }^{76}$ Id. at 681 .
} 
did not improve his productivity. ${ }^{77}$ When the ALJ had not improved his productivity two and one-half years later, SSA filed a petition with MSPB to remove the ALJ for good cause. MSPB refused on the basis that SSA had not established good cause to remove the ALJ. ${ }^{78}$

MSPB's unwillingness to help SSA implement its program to improve ALJ productivity explains SSA's decision not even to attempt to enlist MSPB's assistance in implementing its more controversial effort to establish a presumptively acceptable range of favorable and unfavorable decisions and SSA's ultimate decision to abandon that effort. Given the reaction of both the judiciary and MSPB to SSA's past efforts to exercise some degree of control over its ALJs, SSA would have a reasonable prospect of success in a new effort of this type only if it took a new approach. SSA and MSPB could conduct a joint rulemaking to issue a rule that would simultaneously identify a presumptively permissible range of decisions to grant disability benefits and adopt an interpretation of "good cause" that authorizes SSA and MSPB to remove or to otherwise discipline an ALJ for deviating from the presumptively permissible range of decisions without an adequate explanation.

The rule would have to be issued jointly by the two agencies because SSA has exclusive power to issue rules applicable to the disability program ${ }^{79}$ while MSPB has exclusive power to issue rules that define "good cause" for purposes of the statutory provision that authorizes MSPB to remove an ALJ for good cause. ${ }^{80}$ If the agencies

\footnotetext{
${ }^{77}$ SSA v. Goodman, 58 Admin. L. 2d (Pike \& Fisher) 780, 787 (MSPB 1984).

${ }^{78}$ Id. at 789.

${ }^{79}$ See Heckler v. Campbell, 461 U.S. 458 (1983).

${ }^{80}$ See Ramspeck v. Federal Trial Examiners Conference, 345 U.S. 128 (1953); Long v. SSA, 635 F.3d at 534-35.
} 
provided good reasons supported by solid evidence, they would have a good chance of persuading a court to uphold such a rule. ${ }^{81}$

\section{Eliminate nonexertional restrictions as a potential disability}

There is broad agreement that the problem of excessive ALJ grants of disability benefits began as a result of the $1967^{82}$ and $1984^{83}$ amendments to the Social Security Act that had the effect of broadening the category of impairments that can potentially be the basis for a determination that an applicant is permanently disabled. ${ }^{84}$ Most of the dubious grants of benefits by ALJs are attributable to findings that an applicant suffers from nonexertional restrictions, such as mental illness or pain, that are so severe that he cannot perform the functions of any job available in the US economy. ${ }^{85}$ It follows that we could eliminate the problem simply by amending the statute to eliminate nonexertional restrictions as a potential qualifying impairment.

Such a statutory change would have a major disadvantage, however. It would sweep too broadly. There undoubtedly are individuals with mental illnesses and/or pain so severe that it is truly disabling. We should not exclude all such individuals from potential eligibility if we can identify another viable means of addressing the problem of excessive awards to individuals who suffer from less severe mental illness and/or pain.

\footnotetext{
${ }^{81}$ Chevron deference would apply to the agencies' interpretations of their respective statutes. See Richard Pierce, I Administrative Law Treatise $\$ 3.5\left(5^{\text {th }}\right.$ ed. 2010).

${ }^{82}$ Social Security Act Amendments of 1967, codified at 42 U.S.C. $\$ 423(d)(2)(A)$.

${ }^{83}$ Social Security Disability Benefits Reform Act of 1984, codified at 42 U.S.C. $\$ 423(d)(5)$.

${ }^{84}$ See Autor \& Duggan, supra. note 4, at 77-78; Dubin, supra. note 18, at 948-50; Pierce, supra. note 26, at $509-13$.

${ }^{85}$ Text at notes $18-24$ supra.
} 


\section{E. Eliminate the right to appeal to an ALJ}

Finally, we could eliminate completely the right to appeal a denial of disability benefits to an ALJ. The right to appeal to an ALJ is predicated on the belief that an ALJ decision based on an oral hearing is more likely to yield accurate findings than two bureaucratic decisions based on paper hearings, i.e., consideration of written submissions from the applicant and his supporters and from a variety of medical professionals. There is no evidence to support that belief. There are instead many reasons to believe that two independent decisions based on paper hearings are more likely to yield accurate findings than an ALJ decision based on an oral hearing. ${ }^{86}$

The belief that ALJ decisions are more accurate than bureaucratic decisions necessarily is based on some combination of two subsidiary beliefs - that oral hearings are likely to result in more accurate findings than paper hearings and that ALJs are more likely to be unbiased decisionmakers because of their independence from the bureaucracy. Neither of those beliefs is justified.

Making ALJs independent of the agencies that employ them eliminates one potential source of bias, but it simultaneously increases ALJs' vulnerability to other sources of bias. SSA ALJs are located in regional offices. Thus, they decide whether their neighbors are entitled to disability benefits at taxpayer expense. An ALJ can become very popular in the community in which he doles out billions of dollars to applicants for benefits. The desire to be popular in your community can be a powerful source of bias in the SSA disability decisionmaking process. The natural desire to be popular undoubtedly helps to explain the pattern of decisions of the ALJ who granted benefits in 729 of 729

\footnotetext{
${ }^{86}$ Text at notes $18-39$ supra.
} 
cases in the first half of 2011 and 1280 of 1284 cases in 2010, at a cost to taxpayers of $\$ 492,205,000$ in only 18 months. ${ }^{87}$ By all accounts, that ALJ relishes his status as one of the most popular people in his city and county ${ }^{88}$ It is fair to infer that the over 100 ALJs who grant benefits in over $90 \%$ of cases are affected by the same source of bias. ${ }^{89}$

Of course, an ALJ who is independent of and, hence, beyond the control of, the agency that employs him, is unusually vulnerable to other potential sources of bias as well. Thus, for instance, it is impossible to describe the pattern of decisions of one of the two ALJs at the Commodities Future Trade Commission as unbiased. That ALJ has never decided a case in favor of an investor, thus demonstrating beyond any doubt his bias against investors. $^{90}$

The other basis for the belief that oral hearings yield more accurate findings is the widespread assumption that the opportunity of the trier of fact to observe the demeanor of witnesses is an aid to accurate fact-finding. Like the assumption that independence from the government eliminates bias, this assumption is contradicted by a large body of evidence. Numerous studies have found that ability to observe the demeanor of witness is a distraction from the process of finding facts that detracts from the accuracy of the process, rather than an aid to fact finding that improves accuracy. ${ }^{91}$

I accept the findings of social scientists that applicants for benefits value the opportunity for an oral hearing before an ALJ even if the ALJ decides not to grant the

\footnotetext{
${ }^{87}$ Text at notes $39-42$ supra.

${ }^{88}$ See Paletta, note 40, supra.

${ }^{89}$ Text at notes 28-32 supra.

${ }^{90}$ Michael Schroeder, If You've Got a Beef With a Futures Broker, This Judge Isn't for You—in Eight Years at the CFTC, Levine Has Never Ruled for an Investor, Wall Street Journal (Dec. 13, 2000).

${ }^{91}$ Sources cited in note 39 supra.
} 
requested benefits. ${ }^{92}$ I do not believe, however, that we can afford the massive costs of oral hearings before ALJs merely to assist applicants for benefits in their efforts to accept a negative decision. The direct costs of the ALJ decisionmaking process, in the form of the salary and benefits paid to ALJs is well over $\$ 2$ billion per year. ${ }^{93}$ The direct costs of ALJs are dwarfed by their indirect costs, in the form of scores of billions of dollars paid to undeserving applicants for benefits. ${ }^{94}$

We could save scores of billions by removing all of the ALJs who now decide appeals from SSA decisions that deny disability benefits. In 1953 the Supreme Court held that removal of a class of ALJs on the basis of a determination that they are no longer needed or are no longer affordable satisfies the statutory good cause prerequisite for removal. ${ }^{95}$ We could then use the over $\$ 2$ billion dollars in personell cost savings to fund and staff the sorely needed program to review prior awards of benefits to terminate benefits that are now being paid to many thousands of beneficiaries who do not actually satisfy the standard of disability in the Social Security Act. ${ }^{96}$ Based on prior experience, that program would yield returns of eleven dollars for every one dollar we invest in it. ${ }^{97}$

Elimination of the 1400 SSA ALJs would also produce another major benefit to SSA. As Justice (then-professor) Scalia documented in 1979, ALJs impose large costs of two types on agencies. ${ }^{98}$ First, they typically have the highest salaries in the agency. ${ }^{99}$ Second, they occupy a high proportion (24\% to $73 \%)$ of the Senior Executive Service

\footnotetext{
${ }^{92}$ See, e.g., John Thibaut, Laurens Walker, Stephen Latour \& Pauline Holden, Procedural Justice As Fairness, 76 Stan. L. Rev. 1271, 1280-86 (1974). See also Verkuil et al, supra. note 37, at 132-33.

${ }_{93}$ ALJ salaries vary from $\$ 103,900$ to 155,500 . US Office Of Personell Management Salary Table No. 2011-ALJ. Non-cash benefits add at least $30 \%$ to that number.

${ }^{94}$ Text at notes 9-39 supra.

${ }^{95}$ Ramspeck v. Federal Trial Examiners Conference, 345 U.S. 128, 140-43 (1953).

${ }^{96}$ Text at 63-68 supra.

${ }^{97}$ Sources cited in notes 66-67 supra.

${ }_{98}^{98}$ Antonin Scalia, The ALJ Fiasco-A Reprise, 65 U. Chi. L. Rev. 57 (1979).

${ }^{99}$ Id. at 69-70.
} 
(SES) positions available at an agency. ${ }^{100}$ The removal of ALJs from SSA would allow SSA to hire a large number of talented people to manage its important programs by freeing up a large number of SES positions for that purpose. As Justice Scalia put it, the decision to allocate a massive proportion of an agency's personell budget and SES positions to ALJs "represents the triumph of the courtroom mystique over reason." 101

A correllary change should accompany the elimination of ALJs from the disability decisionmaking process. District judges should be instructed to review SSA decisions as final decisions based solely on the record created at the agency. At present, district judges are required to permit applicants who appeal a decision denying benefits to obtain a remand to SSA to allow the applicant to introduce new evidence. ${ }^{102}$ That is not the way other agency review proceedings are conducted. ${ }^{103}$ The norm in other contexts is judicial review based solely on the record before the agency. ${ }^{104}$

I anticipate that some people will argue that implementation of my proposal would violate due process. In Mathews v. Eldridge, ${ }^{105}$ the Supreme Court upheld the SSA's sole reliance on paper hearings to terminate disability benefits based on an agency finding that a beneficiary is not disabled. The Court made that decision, however, in the context of a decisionmaking process in which SSA made available to anyone who disagreed with such a determination a post-termination oral evidentiary hearing before an ALJ. ${ }^{106}$ Thus, it would be fair to say that the Eldridge opinion gave rise to a permissible inference that the Court would have required SSA to provide a dissatisfied applicant for

\footnotetext{
${ }^{100}$ Id. at $70-71$.

${ }^{101}$ Id. at 71.

10242 U.S.C. $\$ 205(\mathrm{~g})$.

${ }^{103}$ Mashaw et al, supra. note 20, at 130-36.

${ }^{104}$ Pierce, supra. note 81, at $\$ 11.6$.

105424 U.S. 319 (1976).

${ }^{106}$ Id. at 339-42.
} 
disability benefits the opportunity for an oral evidentiary hearing at some time before or within a reasonable period after SSA makes an initial decision that denies or terminates benefits.

It is highly unlikely that the Court would convert that permissible inference into a holding today, however, for several reasons. First, the reasoning in Eldridge supports the holding in Eldridge and not the inference some read into Eldridge. The Court reasoned that SSA could resolve the kinds of factual disputes that arise in disability disputes with tolerable accuracy based on a paper hearing in which agency officials rely exclusively on written submissions from applicants and doctors. ${ }^{107}$ The Court expressed the view that it was not important for the fact finder to be able to observe the demeanor of witnesses in making this class of decisions. ${ }^{108}$

Second, as I have documented at length elsewhere, the vast majority of federal agencies have replaced oral hearings with written hearings in the context of many types of agency adjudications over the decades since the Court issued its opinion in Eldridge. ${ }^{109}$ Some courts initially balked at that dramatic change in the procedures agencies use to adjudicate disputes, but every circuit has now indicated its approval of that change in many contexts. ${ }^{110}$ To paraphrase Justice Scalia, agencies and courts gradually have allowed reason to triumph over the courtroom mystique. ${ }^{111}$ Replacing oral hearings with paper hearings in the context of SSA disability decisions would just be

\footnotetext{
${ }^{107}$ Id. at 344-48. See also Paul Verkuil, A Study of Informal Adjudication, 43 U.Chi. L. Rev. 739, 775-96 (1976) (finding that most agencies provide only notice, an unbiased decisionmaker, and an explanation for each decision the agency makes in an adjudicatory proceeding and explaining why that combination of procedural safeguards satisfies due process in most contexts.

${ }^{108}$ Id. at $344-48$.

${ }^{109}$ Pierce, supra. note 81 at $\$ 8.2$.

${ }^{110}$ See Jack Beerman \& Gary Lawson, Reprocessing Vermont Yankee, 75 Geo. Wash. L. Rev. 856, 875-80 (2007).

${ }^{111}$ See Scalia, note 98 supra., at 71.
} 
another logical step down a road that many agencies and courts have taken with excellent results.

\section{The Present System Is Unconstitutional}

Third, any court that confronts a constitutional challenge to the changes I urge should be influenced by its recognition that the present method of SSA disability decisionmaking is clearly unconstitutional. That conclusion flows inevitably from several characteristic of the present process. First, ALJs make final decisions to grant disability benefits. ${ }^{112}$ Second, SSA ALJs are employed by SSA, which, in turn, is an independent agency headed by a Commissioner who serves a six-year term and who can only be removed by the President for "neglect of duty or malfeasance in office." 113 Third, ALJs can be removed only by the MSPB and only for "good cause." 114 Fourth, the MSPB is an independent agency headed by three members who serve seven-year terms and who can be removed by the President only for "inefficiency, neglect of duty, or malfeasance in office." 115

Each of those characteristics has important legal consequences. Because ALJs make final decisions to grant benefits, they are "officers of the United States" rather than

employees. In Landry v. FDIC, ${ }^{116}$ the D.C. Circuit resolved a dispute with respect to the legal status of ALJs who work at the Federal Deposit Insurance Corporation. The

\footnotetext{
${ }^{112}$ Text at notes $16-17$ supra.

11342 U.S.C. $\$ 902$ (a)(3).

1145 U.S.C. $\$ 7521$.

1155 U.S.C. $\$ 1202$.

${ }^{116} 204$ F.3d 1125 (D.C. Cir. 2000).
} 
petitioner argued that he had been the subject of an unlawful decision because the ALJ who issued an initial decision adverse to the petitioner was an "officer of the United States" who had not been appointed in a manner consistent with the Appointments Clause. ${ }^{117}$ The court held, two-to one, that FDIC ALJs are employees, rather than officers. ${ }^{118}$

The dissenting judge expressed the view that FDIC ALJs are officers. ${ }^{119}$ The majority based its disagreement with that conclusion exclusively on one characteristic of the FDIC decisionmaking process. Like most agencies, FDIC's rules authorize an ALJ only to make an "initial decision." ${ }^{120}$ The FDIC rules empower the agency to substitute its opinion, including its findings of fact, for the initial decision of an ALJ. ${ }^{121}$ The majority concluded that the lack of the power to make a final decision was "critical" to its decision that FDIC ALJs are employees rather than officers. ${ }^{122}$ The majority made it clear that it would agree with the dissenting judge if FDIC ALJs had the power to make final decisions. ${ }^{123}$ SSA's rules allow an appeal of an ALJ decision to a higher authority in the agency only at the behest of an applicant whose application for benefits has been denied by an ALJ. ALJ decisions that grant benefits are final. They are not reviewable by any institution of government. Thus, it is clear that SSA ALJs are "officers" as that term is used in the constitution.

\footnotetext{
${ }^{117}$ Id. at 1128.

${ }^{118}$ Id. at 1134 .

${ }^{119}$ Id. at 1140 .

${ }^{120}$ Id. at 1133 .

${ }^{121}$ Id. at 1133 .

${ }^{122}$ Id. at 1134 .

${ }^{123}$ Id. at $1133-34$.
} 
The holding in the Supreme Court's 2010 opinion in Free Enterprise Fund v. Public Company Accounting Board $(P C A O B)^{124}$ applies directly to SSA ALJs. In $P C A O B$, the Court held unconstitutional the statutory limit on the power of the Securities Exchange Commission (SEC) to remove members of the Board because of what the Court assumed to be the statutory limits on the President's power to remove SEC members. As the Court framed the question before it:

The question is whether these separate layers of protection may be combined. May the President be restricted in his ability to remove a principal officer, who is in turn, restricted in his ability to remove an inferior officer, even though that inferior officer determines the policy and enforces the laws of the United States?

We hold that such multilevel protection from removal is contrary to Article II's vesting of the executive power in the President. ${ }^{125}$

The Court then explained its holding:

This novel structure does not merely add to the Board's independence, but transforms it. Neither the President nor anyone who is directly responsible to him, nor even an officer whose conduct he may review only for good cause, has full control over the Board. The President is stripped of the power our precedents have preserved, and his ability to execute the laws -- by holding his subordinates accountable for their conduct — is impaired.

That arrangement is contrary to Article II's vesting of the executive power in the President. ${ }^{126}$

\footnotetext{
124130 S.Ct. 3138 (2010).

${ }^{125}$ Id. at 3147.

${ }^{126}$ Id. at 3154.
} 
The unconstitutionality of the multiple layers of insulation of SSA ALJs from the President follows a fortiori from the holding and reasoning in $P C A O B$. Indeed, SSA ALJs may even be "principal officers," rather than "inferior officers." To be an "inferior officer," an officer must be inferior to someone. The Court has used two criteria to decide whether an officer is an inferior to a principal officer - the extent of the principal officer's ability to overrule the officer's decisions and the extent of the principal officer's ability to remove the officer. ${ }^{127}$ In theory, SSA ALJs work for the Social Security Commissioner. The Commissioner has not attempted to overrule an ALJ decision to grant disability benefits in decades, however, and he lacks the resources needed to review more than a tiny fraction of such decisions even if he were to decide to devote some of the agency's scarce resources to that task. The Commissioner has no power to remove an ALJ for any reason. Incredibly, the Commissioner is forbidden even to evaluate the performance of ALJs. ${ }^{128}$ The Commissioner's only relevant power is the power to petition the MSPB to remove an ALJ for "good cause." That is far short of the powers that the Court requires a principal officer to have with respect to another officer in order to render the other officer "inferior" to the principal officer.

SSA ALJs are insulated from presidential control by three layers of restrictions on the President's power over the executive branch. An SSA ALJ can only be removed by MPSB for "good cause" in response to a petition for removal filed by SSA. An MSPB member can only be removed by the President for "inefficiency, neglect of duty, or malfeasance in office." The Social Security Commissioner can only be removed by the President for "neglect of duty or malfeasance in office." Since SSA ALJs are officers of

\footnotetext{
${ }^{127}$ The Court discussed and applied those criteria in Edmond v. United States, 520 U.S. 651, 662-66 (1997).

${ }^{128}$ Verkuil, et al, supra. note 37, at 152-62.
} 
the United States, there is no doubt that the three layers of removal limits that insulate SSA ALJs from presidential control are unconstitutional. ${ }^{129}$

I expect that the ALJ who was suspended by the Commissioner in the wake of the Wall Street Journal article exposing him as a judge who decides all cases in favor of applicants will seek review of the Commissioner's action in court. If so, that case will provide an ideal vehicle for a judicial opinion that holds the statutory limits on the power to remove SSA ALJs unconstitutional. Indeed, that is the only means through which the Commissioner can attempt to defend his decision to suspend the ALJ, since he is prohibited by statute from taking any action against an ALJ, specifically including suspension.

\section{Conclusion}

SSA ALJs are responsible for about 2 per cent of total federal spending in 2011 budget - an amount equivalent to 6 per cent of the 2011 budget deficit. ${ }^{130}$ Yet, they are accountable to no one. As a result of this blatantly unconstitutional allocation of power, some SSA ALJs are engaging in unprecedented binge spending while the President and Congress are desperately attempting to identify and to implement the massive spending

\footnotetext{
${ }^{129}$ In a thoughtful article, retired ALJ Jerome Nelson has relied on dicta in the $P C A O B$ opinion to support his contention that the statutory limits on the power of independent agencies to remove ALJs are not unconstitutional. Jerome Nelson, Administrative Law Judges' Removal "Only for Cause:" Is That Administrative Procedure Act Protection Now Unconstitutional? 63 Admin. L. Rev. 401 (2011). I find Judge Nelson's argument persuasive in the context of most ALJs for the same reasons that I agree with the D.C. Circuit's decision that FDIC ALJs are employees rather than officers. Landry v. FDIC, 204 F.3d 1125. ALJs at agencies other than SSA have only the power to issue an initial decision that the agency is free to reject and to replace with its own opinion. By contrast, SSA ALJs are officers because they can and do routinely make highly discretionary final decisions to commit billions of dollars of taxpayer funds. See text at notes 16-17 supra.

${ }^{130}$ SSA disability payments total $\$ 124$ billion per year. SSA ALJs have committed about two-thirds of that total. See text at notes 10-17 supra. The budget for FY 2011 is \$3834 billion; the projected deficit for FY 2011 is $\$ 1267$ billion. OMB, Budget of the United States: Fiscal Year 2011.
} 
cuts in virtually all other parts of the budget that are essential to restore a sustainable fiscal policy for the nation.

There are several ways in which we can attempt to address this problem. My preferred solution would be to abolish the ALJ-administered part of the disability decisionmaking process and to use at least part of the resulting savings to implement a system of reviewing past decisions to grant disability benefits to determine whether each beneficiary actually suffers from a permanent disability so serious that he can not perform the functions needed to hold any job in the US economy. 